\title{
KOMPARASI KINERJA KEUANGAN LEMBAGA AMIL ZAKAT
}

\author{
Prayogo P. Harto, Vivi Sufi Anggraeni, Ai Nur Bayinah \\ Program Studi Akuntansi Syariah, Sekolah Tinggi Ekonomi Islam SEBI \\ Email:prayogo.p.harto@gmail.com,visufi08@gmail.com,ainur.bayinah@gmail.com
}

\begin{abstract}
This study aims to determine the financial performance of zakat institutions. Measurement of financial performance by using financial ratios listed in the International Standard of Zakat Management (ISZM). The financial ratio consists of components of efficiency and capacity. The Objects used in this study are financial and/or annual report of zakat institutions. The results of this study indicate that in terms of efficiency, the institutions of zakat can be said to have been efficient in carrying out its operational activities, but in terms of capacity should still be improved.
\end{abstract}

Keywords: Zakat, Financial Ratios, Efficiency Performance, Capacity Performance

\section{PENDAHULUAN}

Potensi penerimaan zakat di Indonesia terus meningkat sejak tahun 2011. Berdasarkan data Badan Amil Zakat Nasional (BAZNAS) bahwa pada tahun 2017 potensi penerimaan zakat Indonesia sebesar Rp217 triliun. Namun pada kenyataannya potensi yang ada ini belum sepenuhnya terealisasi.

Tabel 1. Perbandingan Potensi Zakat dan Realisasi Zakat

\begin{tabular}{cccc}
\hline Tahun & $\begin{array}{c}\text { Potensi Penerimaan } \\
\text { Zakat* }\end{array}$ & Realisasi Zakat** & Presentase \\
\hline 2011 & $\operatorname{Rp~58.961.143.222.174~}$ & $\operatorname{Rp~1.728.864.359.398~}$ & $2,93 \%$ \\
\hline 2012 & $\operatorname{Rp~64.086.440.764.997~}$ & $\operatorname{Rp~2.212.398.951.344~}$ & $3,45 \%$ \\
\hline 2013 & $\operatorname{Rp~69.794.542.095.826~}$ & $\operatorname{Rp~2.639.604.069.729~}$ & $3,78 \%$ \\
\hline 2014 & $\operatorname{Rp~78.374.957.309.348~}$ & $\operatorname{Rp~3.300.000.000.000~}$ & $4,21 \%$ \\
\hline 2015 & $\operatorname{Rp~82.609.152.671.724~}$ & $\operatorname{Rp~3.650.369.012.964~}$ & $4,42 \%$ \\
\hline 2016 & $\operatorname{Rp~104.000.000.000.000~}$ & $\operatorname{Rp~3.738.216.792.496~}$ & $3,59 \%$ \\
\hline
\end{tabular}

Sumber:* Canggih, Fikriyah, \& Yasin (2017), Wibisono (2016) ** Pusat Kajian dan Strategis (Puskas) BAZNAS (2016), Biro TI dan Pelaporan BAZNAS (2017), data diolah (2017)

Tabel 1 menggambarkan bahwa dari tahun 2011-2016 terus terjadi kesenjangan antara potensi zakat dengan realisasinya. Pada tahun 2015 potensi zakat yang ada di Indonesia sebesar Rp82,6 triliun namun yang terealisasi hanya Rp3,6 triliun. Begitupun tahun 2016 potensi zakat yang terealisasi hanya Rp3,7 triliun (Biro TI dan Pelaporan Badan Amil Zakat 
Nasional, 2017) dari Rp104 triliun (Wibisono, 2016) atau 3,6 \% dari potensi tersebut.

Salah satu penyebab kesenjangan tersebut karena rendahnya kepercayaan masyarakat terhadap lembaga zakat. Riset yang dilakukan PIRAC menyatakan, "Tingkat kepercayaan masyarakat terhadap Lembaga Amil Zakat (LAZ) dan Badan Amil Zakat (BAZ) masih sangat kecil. Responden yang menyalurkan zakatnya ke BAZ dan LAZ hanya 6 dan 1,2\%" (Public Interest Research \& Advocacy Public (PIRAC), 2012).

Ketika LAZ yang ada belum mampu menghimpun dan mengelola besarnya potensi zakat, maka adanya kesenjangan tersebut juga dapat disebabkan oleh kinerja LAZ yang rendah. Kinerja LAZ dapat dilihat dari efisiensi pengelolaan sumber dayanya dan produktivitas lembaga tersebut. Kemampuan sebuah LAZ dalam mengelola sumber daya dapat tercermin dalam laporan keuangan yang dipublikasikannya. Kinerja keuangan sangat diperlukan untuk mengukur apakah pengelolaan dana yang dilakukan LAZ sudah efisien dan sejauh mana dana tersebut digunakan dalam menjalankan program dalam rangka penyalurannya (World Zakat Forum dan Indonesia Magnificence of Zakat, 2017).

Di Indonesia sendiri lembaga zakat terdiri atas BAZNAS dan LAZ (Widodo \& Kustiawan, 2001). BAZNAS dibentuk oleh pemerintah sedangkan LAZ dibentuk oleh masyarakat. Jika dilihat pencapaiannya berdasarkan laporan keuangan audit yang telah dipublikasikan, BAZNAS memiliki cukup banyak dana zakat yang belum tersalurkan. Tahun 20142016 jumlah saldo dana zakat BAZNAS terus meningkat tiap tahun. Hal ini dikarenakan pertumbuhan jumlah penerimaan zakat tidak diiringi dengan pertumbuhan jumlah penyaluran zakatnya. Sehingga selisih dari penerimaan dan penyaluran zakat tersebut terus terakumulasikan sampai dengan tahun 2016 yang mencapai angka Rp75 miliar.

Tabel 2. Perbandingan Penerimaan dan Penyaluran Zakat di BAZNAS

\begin{tabular}{cccc}
\hline Tahun & Penerimaan zakat & Penyaluran Zakat & Saldo Dana Zakat \\
\hline 2014 & $\operatorname{Rp~69.865.506.671~}$ & $\operatorname{Rp~64.265.141.159~}$ & $\operatorname{Rp~29.782.741.431~}$ \\
\hline 2015 & $\operatorname{Rp~82.272.643.293~}$ & $\operatorname{Rp~66.766.033.369~}$ & $\operatorname{Rp~45.289.351.355~}$ \\
\hline 2016 & $\operatorname{Rp~97.637.657.910~}$ & Rp 67.727.019.807 & $\operatorname{Rp~75.199.989.458~}$ \\
\hline \multicolumn{4}{c}{ Sumber: Laporan Keuangan BAZNAS Tahun 2014-2016, data diolah (2017) }
\end{tabular}

Secara garis besar saldo dana ini mencerminkan efisiensi penyaluran dan penerimaan zakat, sehingga semakin kecil saldo dana yang dimilikinya maka semakin efisien lembaga zakat tersebut mengelola dana yang ada, yang mengartikan bahwa dana zakat yang diterima tersalurkan dan termanfaatkan dengan baik, melalui program maupun non-program.

Di sisi lain piutang penyaluran BAZNAS di tahun 2016 juga meningkat dari tahun sebelumnya. Dari Rp2,6 miliar tahun 2015 menjadi Rp18,6 miliar. Menurut PSAK 109 Tentang Akuntansi Zakat dan Infak/Sedekah, piutang penyaluran ini adalah zakat yang disalurkan melalui amil lain tetapi belum diterima oleh mustahik non-amil sehinga tidak dapat 
diakui sebagai penyaluran. Hal ini mengindikasikan BAZNAS telah menyalurkan dana melalui amil lain tetapi belum bisa diakui dan dicatat sebagai penyaluran dikarenakan belum ada laporan dari amil tersebut. Jika piutang ini terus meningkat setiap tahunnya maka hal ini dapat membuat laporan keuangan BAZNAS kurang baik karena tidak optimal dalam mengontrol piutang penyalurannya.

Kondisi yang hampir serupa juga terjadi pada Lembaga Amil Zakat Nasional (LAZNAS) Rumah Yatim Mandiri. Pada tahun 2016 jumlah penerimaan zakat meningkat dari tahun sebelumnya. Tetapi lagi-lagi hal ini berbanding terbalik dengan jumlah penyalurannya. Pada tahun 2015 Yatim Mandiri mampu menghimpun dana zakat sebesar Rp9,5 miliar dan di tahun 2016 meningkat menjadi Rp10 miliar. Sedangkan penyaluran zakat pada 2015 sebesar Rp10,3 miliar dan turun pada 2016 menjadi Rp8,8 miliar.

Grafik 1. Perbandingan Penerimaan dan Penyaluran Zakat Yatim Mandiri

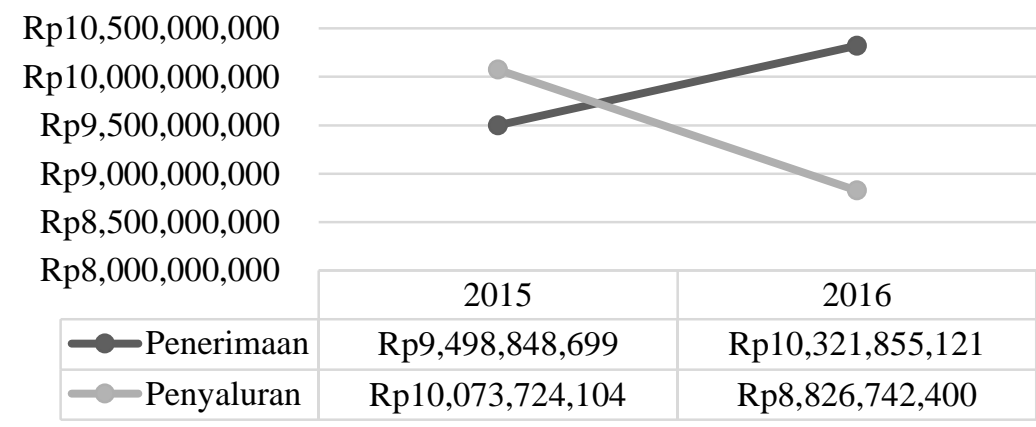

Sumber: Laporan Keuangan LAZNAS Yatim Mandiri 2015-2016, data diolah (2017)

Penelitian terkait kinerja lembaga zakat sudah pernah dilakukan oleh Parisi (2017) dengan menggunakan pendekatan Data Envelpoment Analysis (DEA) yang meneliti efisiensi kinerja keuangan lembaga zakat dari tahun 2010-2013. Berdasarkan penelitian tersebut efisiensi kinerja keuangan BAZNAS mengalami decreasing yakni peningkatan input yang dilakukan tidak sebanding dengan output yang diterima. Hal ini mencerminkan belum efisiennya BAZNAS dalam mengelola sumber daya yang ada. Sebaliknya, lembaga-lembaga amil zakat nasional seperti Dompet Dhuafa, Inisiatif Zakat Indonesia, dan Rumah Zakat justru mengalami increasing yakni kondisi di mana penambahan input menghasilkan output yang lebih besar.

Penelitian lainnya dilakukan oleh Romantin, Bahri, \& Lubis (2017) yang meneliti kinerja keuangan BAZNAS selama periode 2004-2013 berdasarkan lima rasio Ritchie \& Kolodinsky (2003). Hasilnya BAZNAS dinilai mampu mengoptimalkan aset, mampu menghimpun dana, menjalankan program-program yang dimilikinya secara mandiri tanpa bergantung kepada Anggaran Pendapatan dan Belanja Negara (APBN), dan optimal dalam menggunakan sosialisasi dan publikasinya.

Penelitian terkait kinerja keuangan lembaga zakat memang sudah beberapa kali dilakukan, namun belum ada atau masih sangat terbatas 
penelitian yang membandingkan kinerja keuangan BAZNAS dengan Lembaga Amil Zakat Nasional (LAZNAS) dengan menggunakan indikator yang disusun International Standard of Zakat Management (ISZM) International Standard of Zakat Management (ISZM).

Indikator kinerja keuangan lembaga zakat ISZM pertama kali dipublikasikan pada tahun 2017. Juwaini (2015) dalam (World Zakat Forum dan Indonesia Magnificence of Zakat, 2017) mengatakan bahwa "ISZM ini akan menjadi alat dan panduan untuk menilai kualitas lembaga manajeman zakat tingkat dunia" (Muftasany, 2015).

Dalam ISZM tersebut terdapat indikator pengukuran kinerja keuangan yang meliputi atas 2 komponen yakni efisiensi dan kapasitas. Pada komponen pengukuran efisiensi terdiri rasio beban program (program expense ratio), rasio beban operasional (operational expense ratio), rasio beban penghimpunan dana (fundraising expense ratio), dan efisiensi penghimpunan dana (efficiency fundraising). Sedangkan komponen pengukuran kapasitas terdiri atas pertumbuhan penerimaan utama (primary revenue growth), pertumbuhan beban program (program expense growth) dan rasio modal kerja (working capital ratio). Oleh karena itu, penelitian ini akan fokus membandingkan kinerja keuangan lembaga zakat nasional dengan menggunakan indikator kinerja keuangan yang disusun oleh ISZM.

\section{KAJIAN TEORI}

\subsection{KONSEP LEMBAGA ZAKAT}

Lembaga Zakat adalah institusi atau organisasi yang aktivitas utamanya adalah mengelola dana zakat, infaq dan shadaqah (Widodo \& Kustiawan, 2001). Adapun menurut PSAK Syariah 109 (2017) lembaga zakat yakni amil adalah entitas pengelola zakat yang dikukuhkan berdasarkan peraturan undang-undang untuk mengumpulkan dan menyalurkan dana zakat dan infak/sedekah. Sehingga lembaga zakat tergolong kedalam organisasi yang bersifat non-profit oriented atau organisasi nirlaba.

Lembaga zakat di Indonesia yang ada saat ini memiliki bentuk yang berbeda-beda dan berbadan hukum tersendiri (Forum Zakat, 2012). Berdasarkan Undang-Undang No. 23 Tahun 2011, Pengelolaan Zakat adalah kegiatan perencanaan, pengorganisasian, pelaksanaan dan pengawasan terhadap pengumpulan, pendistribusian dan pendayagunaan zakat. Lembaga zakat di Indonesia terdiri atas Badan Amil Zakat Nasional dan Lembaga Amil Zakat Nasional (Widodo \& Kustiawan, 2001).

Badan Amil Zakat Nasional (BAZNAS) adalah lembaga zakat yang dibentuk oleh pemerintah yang merupakan organisasi non-struktural yang bertanggung jawab langsung kepada presiden melalui menteri yakni menteri agama (Romantin, Bahri, \& Lubis, 2017). Dalam UU No. 23 Tahun 2011 tentang Pengelolaa Zakat disebutkan bahwa "Badan Amil Zakat Nasional yang selanjutnya disebut BAZNAS adalah lembaga yang melakukan pengelolaan zakat secara nasional" (pasal 1). Dalam kegiatan pengumpulan, 
pendistribusian, dan pendayaguaan zakat, BAZNAS dibantu dengan LAZ (Keputusan Menteri Agama Republik Indonesia No. 333 Tahun 2015).

LAZ adalah lembaga zakat yang dibentuk bukan oleh pemerintah langsung melainkan oleh masyarakat maupun organisasi masyarakat. Menurut Widodo \& Kustiawan (2001) LAZ adalah organisasi pengelola zakat yang sepenuhnya dibentuk oleh masyarakat yang kemudian dikukuhkan oleh pemerintah. Pengertian LAZ dalam Undang-Undang No.23 Tentang Pengelolaan Zakat adalah "LAZ adalah lembaga yang dibentuk masyarakat memiliki tugas membantu pengumpulan, pendistribusian dan pendayagunaan zakat" (pasal 1).

\subsection{KONSEP KINERJA LEMBAGA ZAKAT}

Kinerja merupakan hal yang penting bagi setiap perusahaan. Menurut Nisvianti \& Andoko (2013) kinerja merupakan tingkat prestasi yang mampu dicapai perusahaan atau organisasi dalam periode tertentu yang mana hal ini adalah faktor penting yang digunakan untuk mengukur efektivitas dan efisiensi organisasi. Kinerja juga merupakan hasil evaluasi terhadap pekerjaan yang telah dilakukan sebuah lembaga atau organisasi, yang mana hasil pekerjaan tersebut dibandingkan dengan kriteria yang telah ditetapkan (Sujarweni, 2017).

Tidak hanya bagi perusahaan, kinerja keuangan juga sangat diperlukan bagi lembaga zakat. Terutama dikarenakan lembaga zakat tersebut merupakan lembaga intermediasi yang mengelola dana umat sehinggga perlu adanya transparansi terkait pengelolaan sumber daya yang dimiliki. Menurut World Zakat Forum \& Indonesia Magnificence of Zakat (2017) bagi lembaga zakat, kinerja keuangan sangat diperlukan untuk mengukur apakah pengelolaan dana yang dilakukan oleh lembaga zakat tersebut sudah efisien dan untuk melihat sejauh mana dana tersebut digunakan dalam menjalankan program penyaluran yang dimiliki. Sehingga akan terlihat pencapaian lembaga zakat dalam mengelola dana umat. Ketika lembaga zakat tidak bisa efisien dalam mengelola dana, akan berdampak pada berkurangnya kepercayaan muzaki untuk membayar zakat.

Setiap jenis perusahaan menggunakan alat analisis dan metode pengukuran kinerja keuangan tertentu yang disesuaikan dengan kebutuhan yang relevan untuk diterapkan (Romantin, Bahri, \& Lubis, 2017). Pengukuran kinerja keuangan ini bertujuan untuk menganalisis kinerja keuangan lembaga zakat dalam satu periode tertentu dengan menggunakan sebuah alat ukur atau alat analisis tertentu yang sesuai.

Pengukuran kinerja keuangan lembaga zakat telah dilakukan dalam beberapa penelitian dengan menggunakan beberapa pendekatan-pendekatan yang berbeda, salah satunya menggunakan Data Envelopment Analysis (DEA). Pendekatan DEA biasanya digunakan untuk meneliti tingkat efisiensi kinerja keuangan lembaga zakat. DEA merupakan alat analisis yang digunakan untuk mengevaluasi kinerja aktivitas sebuah organisasi dengan membandingkan input-ouput dari suatu organisasi data (Decision Making Unit/DMU) dengan output-input lainnya pada DMU sejenis (Hadinata \& 
Manurung, t.t). Metode DEA ini memiliki beberapa pendekatan yakni pendekatan produksi, aset dan intermediasi (Nurhasanah \& Lubis, 2017). Selanjutnya balanced scorecard adalah salah satu metode untuk mengukur kinerja lembaga zakat (Lestari, 2010) melalui perspektif keuangan, perspektif proses internal, perspektif kepuasan pelanggan, serta perspektif inovasi organisasi dan peningkatan aktivitas (Kaplan \& Norton, 1992).

\subsection{KONSEP KINERJA MODEL ISZM}

Pengukuran kinerja keuangan lembaga zakat yang tercantum dalam International Standard of Zakat Management (ISZM) terdiri atas pengukuran terhadap efisiensi lembaga zakat dan pengukuran terhadap kapasitas organisasi.

Pengukuran komponen efisiensi ini akan memperlihatkan apakah pengelolaan dana yang dilakukan lembaga zakat sudah efisien atau belum. Lembaga zakat yang dikatakan efisien apabila mengeluarkan sedikit biaya untuk mendapatkan penghimpunan dana dimana usaha penghimpunan ini harus sejalan dengan program dan pelayanan lembaga zakat (PEBS-FEUI \& IMZ, 2010). Berdasarkan hal tersebut maka pengeluaran yang dilakukan lembaga zakat harus lebih banyak digunakan untuk program dan pelayanannya.

Efisiensi pengelolaan zakat dapat diukur dengan rasio beban program, rasio beban operasional, rasio beban penghimpunan dan efisiensi penghimpunan (World Zakat Forum dan Indonesia Magnificence of Zakat, 2017).

Rasio beban program didapat dengan membagi total biaya program dengan total biaya yang dikeluarkan lembaga zakat selama satu tahun. Biaya program yang dimaksudkan adalah pengeluaran yang ditujukan untuk pemberdayaan mustahik. Sehingga akan terlihat perbandingan besar pengeluaran untuk menjalankan program dengan total seluruh pengeluaran. Semakin besar hasilnya maka semakin baik.

Beban operasional adalah pengeluaran lembaga zakat untuk kegiatan operasional, yang mana hal ini tercermin dalam penggunaan dana amil. Rasio ini didapat dengan membandingkan total pengeluaran untuk operasional dengan keseluruhan pengeluaran. Maka akan diketahui besaran komposisi beban operasional dari total pengeluaran. Berapa banyak yang dikeluarkan lembaga zakat untuk operasionalnya. Jika hasilnya terlalu besar dari total keseluruhan pengeluaran maka dapat disimpulkan bahwa lembaga zakat belum efisien dalam mengelola beban operasionalnya. Seharusnya pengeluaran lembaga zakat lebih fokus kepada program-program dan pelayanan untuk mustahik.

Beban penghimpunan dalam lembaga zakat adalah biaya-biaya yang dikeluarkan dalam rangka penghimpunan dana, seperti biaya iklan, sosialisasi dll. Rasio beban penghimpunan didapat dengan membagi total beban penghimpunan dengan keseluruhan beban atau pengeluaran lembaga zakat. Apabila beban penghimpunan dana ini lebih besar dari pada penghimpunan 
dana yang didapat oleh lembaga zakat maka perlu dipertanyakan bagaimana kinerja lembaga tersebut dalam mengelola keuangannya.

Rasio efisiensi penghimpunan didapat dengan membagi total biaya yang dikeluarkan untuk menghimpun dana dengan total kontribusi yang diberikan oleh muzakki atau penghimpunan dana dari muzakki. Maka berdasarkan hal tersebut dapat diketahui berapa banyak yang dikeluarkan oleh lembaga zakat untuk menghasilkan setiap 1 rupiah penghimpunan. Akan semakin baik apabila jumlah dana yang dikeluarkan oleh lembaga zakat untuk menghasilkan setiap 1 rupiah kontribusi nilainya rendah, sehingga mencerminkan bahwa lembaga zakat tersebut telah efisien.

Perlunya analisis terhadap kapasitas lembaga zakat adalah untuk menentukan seberapa jauh keberlangsungan program dan pelayanan lembaga zakat dan seperti apa lembaga zakat dapat mempertahankannya (PEBS-FEUI \& IMZ, 2010). Pengukuran kapasitas lembaga zakat menurut ISZM terdiri atas rasio pertumbuhan penerimaan dana, rasio pertumbuhan beban program dan rasio modal kerja.

Rasio pertumbuhan penghimpunan dana ini akan berdampak bagi perencanaan penyaluran dan ekspansi lembaga zakat (World Zakat Forum dan Indonesia Magnificence of Zakat, 2017). Rasio ini didapatkan dengan mencari selisih dari penghimpunan dana zakat di tahun berjalan dengan tahun sebelumnya kemudian dibandingkan dengan penghimpunan dana tahun sebelumnya.

Rasio pertumbuhan beban program didapatkan dengan membandingkan selisih beban program tahun berjalan dari tahun sebelumnya dengan beban program tahun sebelumnya. Analisis pertumbuhan beban program ini diperlukan untuk mempertahankan dukungan publik yang luas untuk melaksanakan program-program lembaga zakat.

Rasio modal kerja didapat dengan membandingkan modal kerja dengan total beban lembaga zakat. Analisis modal kerja dibutuhkan untuk menentukan berapa lama lembaga zakat dapat mempertahankan programnya saat ini tanpa menghasilkan pendapatan baru.

\section{METODE PENELITIAN}

Populasi dalam penelitian ini adalah BAZNAS Pusat dan seluruh LAZNAS di Indonesia. Dalam penelitian ini sampel penelitian dipilih dengan menggunakan teknik pengambilan sampel purposive sampling. Teknik purposive sampling merupakan teknik pengambilan sampel oleh peneliti berdasarkan pertimbangan tertentu yang telah ditetapkan sebelumnya (Sugiyono, 2008).

Tabel 3. Pertimbangan Pemilihan Sampel

\begin{tabular}{clc}
\hline No & \multicolumn{1}{c}{ Keterangan } & Jumlah \\
\hline 1 & $\begin{array}{l}\text { Lembaga Zakat yang mendapatkan verifikasi BAZNAS } \\
\text { dan memiliki SK dari Kementrian Agama dan/atau }\end{array}$ & 18 \\
& Keputusan Presiden RI sebagai Lembaga Zakat Nasional
\end{tabular}




\begin{tabular}{llc}
\hline 2 & $\begin{array}{l}\text { Lembaga Zakat Nasional yang tidak menerapkan } \\
\text { transparansi laporan keuangan yang telah diaudit di media } \\
\text { online }\end{array}$ & (12) \\
\hline $3 \quad \begin{array}{l}\text { Lembaga Zakat Nasional yang tidak memiliki laporan } \\
\text { keuangan audit tahun 2014-2016 }\end{array}$ & 4 \\
\hline Jumlah Sampel Penelitian & 3 \\
\hline Periode tahun analisis & 12 \\
\hline Jumlah data penelitian selama periode penelitian
\end{tabular}

Berdasarkan pertimbangan di atas maka terpilihlah 4 lembaga zakat nasional yang memenuhi kriteria sampel dalam penelitian ini yakni yakni BAZNAS Pusat dan 3 LAZNAS yang terdiri dari Yatim Mandiri, Rumah Yatim Arrohman serta Rumah Zakat.

Penelitian Penelitian ini menganalisis data laporan keuangan sehingga diketahui bagaimana kinerja keuangan BAZNAS dan LAZNAS selama 3 periode yakni tahun 2014 hingga tahun 2016. Variabel yang digunakan dalam penelitian ini berupa rasio-rasio keuangan yang terdapat dalam ISZM. Rasiorasio keuangan tersebut digunakan untuk mengukur komponen efisiensi dan komponen kapasitas lembaga zakat.

Tabel 4. Variabel Pengukuran Kinerja Keuangan ISZM

\begin{tabular}{|c|c|c|c|}
\hline No & Indikator & Rumus & Keterangan \\
\hline \multicolumn{4}{|c|}{ Varibel Efisiensi } \\
\hline 1 & $\begin{array}{l}\text { Rasio Beban } \\
\text { Program }\end{array}$ & $\frac{P E}{T E}$ & $\begin{array}{l}P E=\text { Program Expense (Beban } \\
\text { Program) yakni pengeluaran lembaga } \\
\text { zakat untuk program } \\
T E=\text { Total Expense (Total Beban), } \\
\text { yakni keseluruhan pengeluaran }\end{array}$ \\
\hline 2 & $\begin{array}{l}\text { Rasio Beban } \\
\text { Operasional }\end{array}$ & $\frac{O E}{T E}$ & $\begin{array}{l}\text { OE }=\text { Operational Expense (Beban } \\
\text { operasional), yakni pengeluaran } \\
\text { lembaga zakat untuk membiayai } \\
\text { kegiatan operasionalnya } \\
T E=\text { Total Expense (Total Beban), } \\
\text { yakni keseluruhan pengeluaran }\end{array}$ \\
\hline 3 & $\begin{array}{l}\text { Rasio Beban } \\
\text { Penghimpunan }\end{array}$ & $\frac{F E}{T E}$ & $\begin{array}{l}F E=\text { Fundraising Expense (Beban } \\
\text { Penghimpunan), yakni pengeluaran } \\
\text { yang dilakukan lembaga zakat dalam } \\
\text { rangka menghimpun dana } \\
T E=\text { Total Expense (Total Beban), } \\
\text { yakni keseluruhan pengeluaran }\end{array}$ \\
\hline 4 & $\begin{array}{l}\text { Efisiensi } \\
\text { Penghimpunan }\end{array}$ & $\frac{F E}{T C}$ & $\begin{array}{l}F E=\text { Fundraising Expense (Beban } \\
\text { Penghimpunan), yakni pengeluaran } \\
\text { yang dilakukan lembaga zakat dalam } \\
\text { rangka menghimpun dana }\end{array}$ \\
\hline
\end{tabular}




\begin{tabular}{|c|c|c|c|}
\hline & & & $\begin{array}{l}\text { TC = Total Contribution (Total } \\
\text { Kontribusi), yakni total dana } \\
\text { kontribusi dari muzakki maupun } \\
\text { donatur }\end{array}$ \\
\hline \multicolumn{4}{|c|}{ Variabel Kapasitas } \\
\hline 1 & $\begin{array}{l}\text { Pertumbuhan } \\
\text { Penerimaan } \\
\text { Utama }\end{array}$ & $\frac{P R_{n}-P R_{n-1}}{P R_{n-1}}$ & $\begin{array}{l}P R_{n}=\text { Primary Revenue (Penerimaan } \\
\text { Utama) tahun berjalan, yakni total } \\
\text { zakat yang dihimpun ditahun berjalan } \\
P R_{n-1}=\text { Primary Revenue } \\
\text { (Penerimaan Utama) tahun } \\
\text { sebelumnya, yakni total zakat yang } \\
\text { dihimpun tahun sebelumnya }\end{array}$ \\
\hline 2 & $\begin{array}{l}\text { Pertumbuhan } \\
\text { Beban } \\
\text { Program }\end{array}$ & $\frac{P E_{n}-P E_{n-1}}{P E_{n-1}}$ & $\begin{array}{l}P E_{n}=\text { Program Expense (beban } \\
\text { program) tahun berjalan } \\
P E_{n-1}=\text { Program Expense (beban } \\
\text { program) tahun sebelumnya }\end{array}$ \\
\hline 3 & $\begin{array}{l}\text { Rasio Modal } \\
\text { Kerja }\end{array}$ & $\frac{W C p}{T E}$ & $\begin{array}{l}W C p=\text { Working Capital (Modal } \\
\text { Kerja), yakni saldo dana amil yang } \\
\text { digunakan untuk operasional } \\
\text { lembaga zakat } \\
T E=\text { Total Expense (Total Beban), } \\
\text { yakni keseluruhan pengeluaran dana } \\
\text { amil }\end{array}$ \\
\hline
\end{tabular}

Sumber: World Zakat Forum dan Indonesia Magnificence of Zakat (2017)

\section{PEMBAHASAN}

Pengukuran rasio beban program bertujuan untuk melihat pengeluaran yang dilakukan lembaga zakat untuk penyaluran kepada mustahik. Semakin besar hasilnya maka akan semakin baik. Hal ini menandakan bahwa semakin baik fungsi kerja yang dihasilkan lembaga tersebut, karena semakin banyak pengeluaran yang ditujukan untuk pemberdayaan mustahik. Pembandingkan rasio beban program dilakukan untuk menilai lembaga zakat mana yang memiliki efisiensi penyaluran dana terbaik.

Tabel 5. Perbandingan Rasio Beban Program

\begin{tabular}{lcccc}
\hline \multicolumn{1}{c}{ Lembaga Zakat } & 2014 & 2015 & 2016 & Rata-Rata \\
\hline BAZNAS & $81 \%$ & $80 \%$ & $73 \%$ & $78 \%$ \\
\hline Yatim Mandiri & $75 \%$ & $72 \%$ & $76 \%$ & $74 \%$ \\
\hline Rumah Yatim Arrahman & $83 \%$ & $85 \%$ & $90 \%$ & $86 \%$ \\
\hline Rumah Zakat & $8.6 \%$ & $90 \%$ & $90 \%$ & $89 \%$ \\
\hline
\end{tabular}

Sumber: Data diolah (2018) 
Secara keseluruhan perolehan nilai rasio beban program lembaga zakat masih efisien karena masih di atas 70\%. Dengan demikian dapat disimpulkan semua lembaga zakat relatif telah menjalankan fungsinya dalam pemberdayaan mustahik. Dari lembaga zakat yang diukur, Rumah Zakat memiliki rasio beban program yang paling efisien, yaitu rata-rata $89 \%$ selama tiga tahun.

Pengukuran terhadap beban operasional ini diperlukan untuk melihat sejauh mana tingkat efisiensi lembaga zakat dalam mengelola beban operasionalnya terhadap total pengeluaran. Semakin kecil hasilnya maka semakin baik, karena dapat dikatakan bahwa lembaga zakat telah efisien mengelola biaya operasionalnya. Perbandingan terhadap rasio beban operasional ini dilakukan untuk melihat manakah lembaga zakat yang paling efisien dalam mengendalikan beban operasionalnya.

Tabel 6. Perbandingan Rasio Beban Operasional

\begin{tabular}{llllc}
\hline \multicolumn{1}{c}{ Lembaga Zakat } & 2014 & 2015 & 2016 & Rata-Rata \\
\hline BAZNAS & $19 \%$ & $20 \%$ & $27 \%$ & $22 \%$ \\
\hline Yatim Mandiri & $25 \%$ & $28 \%$ & $24 \%$ & $26 \%$ \\
\hline Rumah Yatim Arrahman & $17 \%$ & $15 \%$ & $10 \%$ & $14 \%$ \\
\hline Rumah Zakat & $14 \%$ & $10 \%$ & $10 \%$ & $11 \%$ \\
\hline
\end{tabular}

Sumber: Data diolah (2018)

Hasil dari pengukuran rasio beban opersional mencerminkan semua lembaga zakat telah efisien dalam mengatur proporsi pengeluaran dalam menjalankan kegiatan operasionalnya, di mana biaya operasional tersebut masih berada dalam batasan wajar dan sesuai dengan biaya fungsionalnya. Dari lembaga zakat yang diukur, Rumah Zakat memiliki rasio beban operasional yang paling efisien, yaitu rata-rata $11 \%$ selama tiga tahun.

Pengukuran rasio beban penghimpunan dana ini hampir sama dengan beban operasional yakni untuk mengetahui beban penghimpunan yang dilakukan masih dalam batas wajar dan sesuai dengan fungsinya. Semakin rendah nilainya maka semakin baik. Dari hasil perhitungan semua lembaga zakat tersebut rasio beban penghimpunan dananya masih efisien, yakni ratarata $2-3 \%$ pertahun. Dari lembaga zakat yang diukur, Rumah Zakat memiliki rasio beban penghimpunan dana yang paling efisien, yaitu rata-rata $2 \%$ selama tiga tahun.

Pengukuran rasio efisiensi penghimpunan dana adalah untuk mengetahui berapa banyak lembaga zakat mengeluarkan uangnya untuk dapat menghimpun dana dari muzaki maupun donatur. Jika lembaga zakat mampu menghimpun dana dari muzaki maupun donatur dalam jumlah besar dengan mengeluarkan sedikit biaya, maka ini merupakan hal baik. Kondisi seperti itu mencerminkan bahwa lembaga efisien dalam melakukan penghimpunannya. Namun jika yang terjadi sebaliknya yakni biaya yang dikeluarkan untuk menghimpun dana tidak sebanding dengan dana yang terhimpun, maka yang terjadi adalah inefisiensi. Kondisi seperti itulah yang harus dihindari oleh lembaga zakat. 
Dari hasil perhitungan semua lembaga zakat tersebut masih efisien dalam melakukan kegiatan penghimpunanya, yakni rata-rata Rp0,02 Rp0,03. Dari lembaga zakat yang diukur, Rumah Zakat memiliki rasio efisiensi penghimpunan dana yang paling efisien, yaitu rata-rata $\mathrm{Rp} 0,02$ selama tiga tahun, yang artinya Rumah Zakat hanya perlu mengeluarkan biaya sebesar Rp0,02 untuk dapat menghasilkan penghimpunan dana sebesar Rp1 rupiah.

Pengukuran kapasitas rasio pertumbuhan penerimaan utama adalah untuk menilai kemampuan lembaga zakat dalam meningkatkan dana zakat yang dihimpun dari tahun sebelumnya. Untuk mengukur pertumbuhan penerimaan utama ini dilihat dari jumlah penghimpunan dana zakat pada tahun tersebut apakah terjadi peningkatan dari tahun sebelumnya atau tidak, yakni dengan mencari selisih penghimpunan tahun berjalan dengan tahun sebelumnya kemudian dibandingkan dengan jumlah penghimpuna tahun sebelumnya.

Dengan kata lain rasio ini mencerminkan presentase peningkatan penghimpunan zakat dari tahun sebelumnya. Semakin besar hasilnya tentu akan semakin baik. Jika hasil dari rasio ini bersifat minus, maka ini menandakan bahwa penghimpunan yang dilakukan lembaga zakat tersebut mengalami penurunan dari tahun sebelumnya.

Tabel 7. Perbandingan Pertumbuhan Penghimpunan Utama

\begin{tabular}{lcccc}
\hline \multicolumn{1}{c}{ Lembaga Zakat } & 2014 & 2015 & 2016 & Rata-Rata \\
\hline BAZNAS & $38 \%$ & $18 \%$ & $19 \%$ & $25 \%$ \\
\hline Yatim Mandiri & na & $7 \%$ & $6 \%$ & $7 \%$ \\
\hline Rumah Yatim Arrohman & $-12 \%$ & $15 \%$ & $16 \%$ & $6 \%$ \\
\hline Rumah Zakat & $4 \%$ & $21 \%$ & $12 \%$ & $12 \%$ \\
\hline
\end{tabular}

Sumber: Data diolah (2018)

Dari hasil perhitungan, semua lembaga zakat tersebut rasio penghimpunan dananya relatif masih tumbuh positif, yakni rata-rata 6 - 25\% pertahun, artinya kapasitas lembaga zakat dalam menjalankan kegiatan operasionalnya dapat dianggap baik. Dari lembaga zakat yang diukur, BAZNAS memiliki rasio pertumbuhan penghimpunan dana yang paling baik, yaitu rata-rata $25 \%$ selama tiga tahun.

Pengukuran kapasitas rasio pertumbuhan beban program dilihat dari semakin besar pertumbuhan beban program menandakan bahwa adanya peningkatan penyaluran oleh lembaga zakat kepada mustahik. Seiring dengan bertambahnya penghimpunan yang dilakukan lembaga zakat seharusnya jumlah penyaluran yang disalurkan pun bertambah.

Tabel 8. Perbandingan Pertumbuhan Beban Program

\begin{tabular}{lcccc}
\hline \multicolumn{1}{c}{ Lembaga Zakat } & 2014 & 2015 & 2016 & Rata-Rata \\
\hline BAZNAS & $38 \%$ & $7 \%$ & $8 \%$ & $17 \%$ \\
\hline Yatim Mandiri & na & $16 \%$ & $20 \%$ & $18 \%$ \\
\hline
\end{tabular}




\begin{tabular}{lcccc}
\hline Rumah Yatim Arrohman & $-4 \%$ & $20 \%$ & $54 \%$ & $23 \%$ \\
\hline Rumah Zakat & $4 \%$ & $25 \%$ & $-6 \%$ & $8 \%$ \\
\hline \multicolumn{5}{c}{ Sumber: Data diolah (2018) }
\end{tabular}

Dari hasil perhitungan, semua lembaga zakat tersebut rasio beban programnya relatif masih tumbuh positif, yakni rata-rata $8-23 \%$ pertahun. Hal ini merupakan indikasi yang baik karena lembaga zakat berusaha untuk menyalurkan dana yang dihimpunnya dengan optimal. Kondisi inilah yang seharusnya terjadi pada lembaga zakat. Dari lembaga zakat yang diukur, Rumah Yatim memiliki rasio pertumbuhan beban program yang paling baik, yaitu rata-rata $23 \%$ selama tiga tahun.

Pengukuran kapasitas rasio modal kerja digunakan untuk melihat sejauh mana modal kerja yang dimiliki oleh lembaga zakat mampu menutupi pengeluarannya ketika lembaga zakat tersebut tidak menghasilkan pendapatan baru (dalam hal ini penghimpunan dana baru). Modal kerja dalam lembaga zakat ini dapat tercermin dari saldo dana amil di tahun sebelumnya yang kemudian menjadi saldo awal dana amil tahun berjalan. Semakin besar hasilnya maka semakin baik yang menandakan dana amil yang ada dapat meng-cover beban operasional lembaga zakat.

Tabel 9. Perbandingan Rasio Modal Kerja

\begin{tabular}{lcccc}
\hline \multicolumn{1}{c}{ Lembaga Zakat } & 2014 & 2015 & 2016 & Rata-Rata \\
\hline BAZNAS & $8 \%$ & $1 \%$ & $2 \%$ & $3 \%$ \\
\hline Yatim Mandiri & na & $19 \%$ & $12 \%$ & $16 \%$ \\
\hline Rumah Yatim Arrohman & $25 \%$ & $1 \%$ & $2 \%$ & $9 \%$ \\
\hline Rumah Zakat & $24 \%$ & $32 \%$ & $36 \%$ & $31 \%$ \\
\hline
\end{tabular}

Sumber: Data diolah (2018)

Dari hasil perhitungan, semua lembaga zakat tersebut rasio modal kerjanya relatif masih positif. Hal tersebut menandakan bahwa lembaga zakat masih mampu menutupi pengeluaran operasionalnya dengan saldo dana amil yang ada tanpa menghasilkan penerimaan baru. Dari lembaga zakat yang diukur, Rumah Zakat memiliki rasio modal kerja yang paling baik, yaitu rata-rata $31 \%$ pertahun.

\section{SIMPULAN}

Kinerja keuangan lembaga zakat nasional selama kurun waktu penelitian (2014 - 2016) dapat dikatakan baik. Berdasarkan hasil pengukuran terhadap komponen efisiensi, semua lembaga zakat masih dikatakan efisien. Perolehan nilai dari rasio beban program, rasio beban operasional, rasio beban penghimpunan dan efisiensi penghimpunan dananya masih berada dalam batas wajar atau tidak menyalahi fungsi kerjanya. Begitu pun berdasarkan hasil pengukuran terhadap komponen kapasitas, dari tahun 2014 hingga tahun 
2016, rasio penerimaan utama dari semua lembaga zakat relatif mengalami pertumbuhan positif.

Hal ini mengindikasikan kapasitas lembaga zakat dalam menjalankan kegiatan operasionalnya sudah baik. Demikian juga dengan rasio beban program semua lembaga zakat tumbuh positif yang mengindikasikan lembaga zakat telah berusaha untuk menyalurkan dana yang dihimpunnya dengan optimal. Namun dalam hal rasio modal kerja, meski masih positif, dibutuhkan peningkatan kinerja karena masih ada lembaga zakat yang nilai rasionya tergolong rendah.

\section{DAFTAR PUSTAKA}

Biro TI dan Pelaporan Badan Amil Zakat Nasional. (2017). Statistik Zakat Nasional 2016. Jakarta: Bagian SIM dan Pelaporan Badan Amil zakat Nasional.

Canggih, C., Fikriyah, K., \& Yasin, A. (2017). Potensi Dan Realisasi Dana Zakat Indonesia. Al-Uqud: Journal of Islamic Economics, 1(1), 14-26.

Forum Zakat. (2012). Cetak Biru Pengembangan Zakat Indonesia 20112025: Panduan Masa Depan Zakat Indonesia. Jakarta: Forum Zakat (FOZ).

Hadinata, I., \& Manurung, A. H. (t.t). Penerapan Data Envelopment Analysis (DEA) Untuk Mengukur Efisiensi Kinerja Reksa Dana Saham. 2.

Kaplan, R. S., \& Norton, D. P. (1992). The Balanced Scorecard-Measures that Drive Performance. Harvard Business Review, 71.

Keputusan Menteri Agama Republik Indonesia No. 333 Tahun 2015. Tentang Pedoman Pemberian Izin Pembentukan Lembaga Amil Zakat. 2015.

Lestari, A. (2015). Efisiensi Kinerja Keuangan Badan Amil Zakat Daerah (BAZDA): Pendekatan Data Envelopment Analysis (DEA). JESP: Jurnal Ekonomi \& Studi Pembangunan, 16(2), 177-187.

Muftasany, H. (2015, November 27). WZF Dorong Perbaikan Pengelolaan Zakat di Dunia. Koran Republika.

Nisvianti, \& Andoko, W. (2013). Studi Komparasi Kinerja Keuangan Bank Syariah Mandiri (Perbankan Syariah) dengan Bank Mandiri (Perbankan Konvensional). Cahaya Aktiva, 3(2), 115.

Nurhasanah, S., \& Lubis, D. (2017). Efisiensi Kinerja BAZNAS Bogor dan Sukabumi: Pendekatan Data Envelopment Analysis. Jurnal Akuntansi dan Keuangan Islam, 5(2), 105-120.

Parisi, S. A. (2017). Tingkat Efisiensi dan Produktivitas Lembaga Zakat di Indonesia. Esensi: Jurnal Bisnis dan Manajemen, 7(1), 63-72. 
PEBS-FEUI \& IMZ. (2010). Menggagas Arsitektur Zakat Indonesia: Menuju Sinergi Pemerintah dan Masyarakat Sipil Dalam Pengelola Zakat Nasional. Jakarta: IMZ.

Peraturan Badan Amil Zakat Nasional No. 03 Tahun 2014. (2014). Organisasi dan Tata Kerja Badan Amil Zakat Nasional Provinsi dan Badan Amil Zakat Nasional Kabupaten/Kota.

PSAK Syariah 109. (2017). Akuntansi Zakat dan Infak/Sedekah. Jakata: IAI.

Public Interest Research \& Advocacy Public (PIRAC). (2012, Mei 25). Mensejahterakan Umat dengan Zakat.

Pusat Kajian dan Strategis (Puskas) BAZNAS. (2016). Outlook Zakat Indonesia 2017. Jakarta: Pusat Kajian Strategis BAZNAS.

Bahri, E. S., Romantin, M., \& Lubis, A. T. (2017). Analisis Kinerja Keuangan Lembaga Zakat (Studi Kasus: Badan Amil Zakat Nasional). Perisai: Islamic Banking and Finance Journal, 1(2), 96-116.

Sugiyono, P. D. (2008). Metode Penelitian Kuantitatif, Kualitatif dan R\&D. Bandung: CV. Alfabeta.

Sujarweni, V. W. (2017). Analisis Laporan Keuangan Teori, Aplikasi, dan Hasil Penelitian. Yogyakarta: Pustaka Baru Press.

Undang-Undang Republik Indonesia No.23 Tahun 2011. (2011). Tentang Pengelolaan Zakat. Jakarta: Dewan Perwakilan Rakyat (DPR).

Wibisono, Y. (2016). Peluang dan Tantangan Pengelolaan. Seminar Zakat Nasional 2016. Depok.

Widodo, H., \& Kustiawan, T. (2001). Akuntansi dan Manajemen Keuangan untuk Organisasi Pengelola Zakat. Tangerang: Institut Manajemen Zakat.

World Zakat Forum dan Indonesia Magnificence of Zakat. (2017). Dalam Juwaini, et.al (Penyunt.), International Standard of Zakat Management ISZM: 2017. Jakarta: IMZ Publisihing.

Badan Amil Zakat Nasional. (2015). Laporan Keuangan Audit Yang Berakhir Pada 31 Desember Tahun 2015 dan 2014. Jakarta: Badan Amil Zakat Nasional.

Badan Amil Zakat Nasional. (2016). Laporan Keuangan Audit Yang Berakhir Pada 31 Desember Tahun 2016 dan 2015. Jakarta: Badan Amil Zakat Nasional.

Badan Amil Zakat Nasional. (2014). Laporan Keuangan Audit Yang Berakhir Pada 31 Desemebr Tahun 2014 Dan 2013. Jakarta: Badan Amil Zakat Nasional. 
Rumah Yatim Arrohman Indonesia. (2014). Laporan Keuangan Audit Yang Berakhir Pada 31 Desember Tahun 2014 dan 2013. Bandung: Yayasan Rumah Yatim Arrohman Indonesia.

Rumah Yatim Arrohman Indonesia. (2015). Laporan Keuangan Audit Yang Berakhir Pada 31 Desember Tahun 2015 dan 2014. Bandung: Yayasan Rumah Yatim Arrohman Indonesia.

Rumah Yatim Arrohman Indonesia. (2016). Laporan Keuangan Audit Yang Berakhir Pada 31 Desember Tahun 2016 dan 2015. Bandung: Yayasan.

Rumah Zakat Indonesia. (2016). Laporan Keuangan Audit Yang Berakhir Pada 31 Desember Tahun 2016 dan 2015. Jakarta: Rumah Zakat Indonesia.

Rumah Zakat. (2014). Laporan Keuangan Audit Yang Berakhir Pada 31 Desember Tahun 2014 dan 2013. Jakarta: Rumah Zakat.

Rumah Zakat. (2015). Laporan Keuangan Audit Yang Berakhir Pada 31 Desember Tahun 2015 dan 2014. Jakarta: Rumah Zakat.

Yatim Mandiri. (2015). Laporan Keuangan Audit Yang Berakhir Pada 31 Desember Tahun 2015 dan 2014. Surabaya: Yayasan Yatim Mandiri.

Yatim Mandiri. (2016). Laporan Keuangan Audit Yang Berakhir Pada 31 Desember Tahun 2016 dan 2015. Surabaya: Yayasan Yatim Mandiri. 
